\title{
The Modelling Study for Potassium Fertilizer Requirements in Hazelnut (Corylus avellana L.)
}

\author{
Nedim ÖZENÇ \\ Ordu University, Vocational School of Technical Sciences, Department of Crop and Animal Production, 52200 Ordu, Turkey; \\ nedimozenc@yahoo.com
}

\begin{abstract}
Potassium is probably the second most important nutrient in hazelnuts (Corylus avellana L.) and an adequate supply of potassium is required for the maximum yield and nuts with high quality. The available amount of this element is often insufficient in soils and must be supplied as fertilizers, which is an essential input for the successful nut agriculture. This modelling study was conducted to determine potassium fertilizer requirement depending on the existing potassium levels of hazelnut orchard soils in the Black Sea Region. The trial was carried out on 'Tombul' (Turkish hazelnut variety) hazelnut orchard in Hazelnut Research Station located in the Black Sea Region, Turkey. It was designed as a randomized complete block design with five potassium doses $\left(0,200,400,600\right.$ and $\left.800 \mathrm{~kg} \mathrm{ha}^{-1} \mathrm{~K}_{2} \mathrm{O}\right)$ and three replications per treatment. Besides, other nutrient elements were applied according to the soil analysis results. During three years, each hazelnut ocak (hazelnut branch planting system) was harvested and their total yield was determined. In order to determine the impact value of existing potassium in soils and fertilizers, Modified Mitcherlich equation $\log (A-y)=\log A-c_{1} \cdot b_{1}$ was used. Using Mitcherlich equation, the impact value of the existing potassium in the trial orchard soils was found as $c_{1}=0.0026$, the impact value of potassium in the fertilizer was found as $c=0.0038$. Potassium fertilizer amounts which should be used according to the contents of various potassium nutrient elements in the soils were calculated by using the $\log (A-y)=\log A-c_{1} b_{1}-c x$ equation. The obtained data were analyzed with regression and to achieve the maximum yield values at different rates, the formula $\mathrm{Y}=\mathrm{a}+\mathrm{b}_{\mathrm{yx}} \mathrm{X}$ can be used on the calculation of the amount of fertilizer. In order to obtain $90 \%, 92 \%, 94 \%, 96 \%, 98 \%$ and $99 \%$ yield out of the maximum product level in hazelnuts, useable models on the potassium fertilizer recommendations were determined as $\mathrm{Y}_{90}=263.0-$ 0.684X, $\mathrm{Y}_{92}=289.0-0.684 \mathrm{X}, \mathrm{Y}_{94}=322.0-0.684 \mathrm{X}, \mathrm{Y}_{96}=368.0-0.684 \mathrm{X}, \mathrm{Y}_{98}=447.0-0.684 \mathrm{X}$ and $\mathrm{Y}_{99}=526.0-0.684 \mathrm{X}$.
\end{abstract}

Keywords: Corylus avellana L., fertilizer, modelling, potassium, yield

\section{Introduction}

Turkey provides $70 \%$ of the world hazelnut requirement with 690.000 hectares hazelnut area and the average annual 580.000 tons yield (Anonymous, 2012; FAO, 2012). Hazelnut has a very important place in the country's agricultural products in terms of the amount of production and export values. In addition, the amount of production in Turkey is to be a very significant impact on the world nut trade and industry (Turkish Hazelnut Exporter's Union, 2012). Despite total amount of hazelnut production is high, the amount of average dry shelled nut (950-1000 $\mathrm{kg} \mathrm{ha}^{-1}$ ) are the lowest compared to other hazelnut producing countries. Lack of obtained product per unit area in Turkey is resulted from some fundamental deficiencies such as set up of the orchards in very slope and shallow soils areas, set up age of the orchards is very old, not made the necessary cultural operation and especially, not made exactly the required fertilization (Köksal, 2002; Okay et al., 1986; Özençet al., 2005; Ünal, 2007).
Potassium is an essential macronutrient for plants. It is the most abundant cation in the cytoplasm, and along with its conjugate anions, makes a major contribution to osmotic potential of cells and tissues and the maintenance of cell turgor pressure (Marschner, 1995).

Potassium has an important role in enzyme activation, protein synthesis and the establishment of trans-membrane $\mathrm{pH}$ and electric charge gradients. In addition, potassium increases the strength of the fruit, has a positive effect in increasing of fat, starch and sugar rates, and improves such as color, taste, and odor properties. There are positive effects on yields because of improving the quality of the product. Potassium strengthens woody tissue of the hazelnut, and reinforces against winter-frost of branches and fungal diseases (Duyar and Özenç, 2013). When there is enough potassium in the soil, nitrogen utilization is increasing, and thus increases the effect on the yield. Moreover, potassium increases the transport of synthesized organic matter in the kernel filling period of nut and this provides more kernel fullness. 
With an average amount of $23 \mathrm{~g} \mathrm{~kg}^{-1}$, potassium is the eight most abundant elements in the earth's crust (Krebs, 2006; Mengel, 2007). Between $90 \%$ and $98 \%$ of total soil potassium is found within the structure of soil minerals and the remaining $2-10 \%$ is found either as fixed or exchangeable and water soluble $\mathrm{K}^{+}$(Brady and Weil, 2007). Exchangeable potassium is adsorbed onto the clay surface of minerals and can be desorbed and come into soil solution according to the equilibrium conditions. Water soluble potassium can be easily absorbed by plant roots. Available potassium is a limiting factor in many agricultural systems and $\mathrm{K}$ fertilizers are widely used in agriculture all over the world. Potassium uptake is mainly based on ion diffusion, which is a mechanism that is sensitive environmental factors such as soil type, precipitation, and temperature (Very and Sentenac, 2003). Potassium deficiency in the about half of the soils of hazelnuts orchards in Black Sea region is seen. Özenç et al. (2005) reported that in the trial orchards (2600 hazelnut orchards), $54.42 \%$ of soils has low potassium content, $18.50 \%$ has medium, $8.04 \%$ has high and $19.04 \%$ has too high and also $80.94 \%$ of these orchards needs to be fertilized with potassium. Extractable potassium content of agricultural soils in Central and Eastern Black Sea Region is low and very low (41.29\%), medium (16.03\%), good (11.09\%), high and too high (31.59\%) (Özyazıcı et al., 2013).

Fertilizing is an important cultural process which recycled back to the soil with fertilizing required nutrient for plant and in this way the yield and quality is increased. However, the expected benefit from the fertilization correlates with true kind, amount of the fertilizer and the application time. Therefore, application of requirement amounts of the fertilizer has great importance according to the plant varieties in the cultivating area. The soil analysis methods were calibrated differentially by many researchers in different countries and regions. Fertilizer recommendations were made according to the results of this study (Kacar and Katkat, 2007). Since relative index values can be provided with chemical soil analysis methods, there occurs an obligation to calibrate these methods for certain plant, soil, climate and agriculture techniques. In this way, the amount of fertilizer can be calculated according to the analysis values. Güçdemir (2006) stated that after having correlation between examined the nutrient substance and the amount of the yield, the fertilizer requirements are determined. Today, the calibrations of chemical analysis methods in hazelnut agriculture have been completed. However, the requirement amounts of fertilizer should be calculated to raise the desired level of yield according to specific analysis values. This research objective was to determine of potassium fertilizer requirements relation for the potassium nutrient element in hazelnut agriculture. For this aim, the calculation of requirement fertilizer values were formulated as being the first time in hazelnut agriculture, and the amount of potassium fertilizer was provided with only one calculation.

\section{Materials and methods}

This research was carried out in Hazelnut Research Station located in Giresun province in the East Black Sea region of Turkey $\left(40^{\circ} 54^{\prime} 33^{\prime \prime} \mathrm{N}, 38^{\circ} 21^{\prime} 01^{\prime \prime} \mathrm{E}\right)$ between the years 2009 and 2011. The elevation was $20-30 \mathrm{~m}$. The experimental region has a temperate climate and is known to be favourable for hazelnut agriculture. The total precipitation amounted to $1324 \mathrm{~mm}$. The mean temperature and relative humidity were $14.2^{\circ} \mathrm{C}$ and $76.0 \%$. In the trial, the prime quality 'Tombul' (Turkish hazelnut variety, Corylus avellana L.) hazelnut was used as a kind of nuts. The experiment was established the average of 20-25 years old. 'Tombul' hazelnut ocak consists of 4 branches based on transplanting system. The experiment was designed as a randomized complete block design with five potassium doses $\left(0,200,400,600\right.$ and $\left.800 \mathrm{~kg} \mathrm{ha}^{-1} \mathrm{~K}_{2} \mathrm{O}\right)$ and three replications per treatment. For the 500 hazelnut ocaks were to be located in one hectare orchard, given potassium fertilizer doses each ocak were calculated as $0,800,1600$, 2400 and $3200 \mathrm{~g} \mathrm{ocak}^{-1} \mathrm{~K}_{2} \mathrm{SO}_{4}$ and these doses were applied during three years. In addition, other fertilizers were applied at required rates in each ocak according to the results of soil analysis. Applied fertilizers were as follows: $1520 \mathrm{~g} \mathrm{ocak}^{-1}$ $5\left[\mathrm{Ca}\left(\mathrm{NO}_{3}\right)_{2} \cdot 2 \mathrm{H}_{2} \mathrm{O}\right] \cdot \mathrm{NH}_{4} \mathrm{NO}_{3}(26 \% \mathrm{~N}), 432 \mathrm{~g}_{\text {ocak }^{-1}}$ $3 \mathrm{Ca}\left(\mathrm{H}_{2} \mathrm{PO}_{4}\right)_{2} \mathrm{H}_{2} \mathrm{O}\left(42-44 \% \mathrm{P}_{2} \mathrm{O}_{5}\right), 1100$ g ocak $^{-1} \mathrm{CaCO}_{3}$ (90\% $\mathrm{CaO}), 2040$ g ocak $^{-1} \mathrm{MgSO}_{4} .7 \mathrm{H}_{2} \mathrm{O}(9.8 \% \mathrm{Mg}), 66.64$ $\mathrm{g}$ ocak $^{-1}$ Fe-EDDHA (12\% Fe), $29.09 \mathrm{~g}_{\text {ocak }}{ }^{-1}$ $\mathrm{Na}_{2} \mathrm{~B}_{4} \mathrm{O}_{7} .10 \mathrm{H}_{2} \mathrm{O}(11 \% \mathrm{~B}), 2.29$ g ocak $^{-1} \mathrm{ZnSO}_{4} \cdot \mathrm{H}_{2} \mathrm{O}(35 \%$ $\mathrm{Zn}), 1.6 \mathrm{~g} \mathrm{ocak}^{-1} \mathrm{CuSO}_{4 .} .5 \mathrm{H}_{2} \mathrm{O}, 16.0 \mathrm{~g} \mathrm{ocak}^{-1} \mathrm{MnSO}_{4}(25 \%$ $\mathrm{Mn})$ and $1.6 \mathrm{~g} \mathrm{ocak}^{-1}\left(\mathrm{NH}_{4}\right)_{6} \mathrm{Mo}_{7} \mathrm{O}_{24} \cdot 4 \mathrm{H}_{2} \mathrm{O}(54 \% \mathrm{Mo})$.

Texture analysis of the experiment soils were performed according to Soil Survey Staff (1951), pH and EC analyses according to U. S. Salinity Lab. Staff (1954), $\mathrm{CaCO}_{3}$ analysis according to Çağlar (1958), organic matter content according to Nelson and Sommers (1982), available phosphorus according to Bray and Kurtz (1945) and available potassium according to Knudsen et al. (1982) were done. Required fertilizers were applied in the hazelnut orchards during three years. Cultural maintenance in hazelnut orchards were made throughout the year such as pruning, weed control, disease and insect control, etc. Each a hazelnut ocak was harvested separately in the first week of August depending on climate (Ayfer et al., 1986; Köksal, 2002). Harvested hazelnuts were separated from husk and dried in natural conditions. The dry shelled nut yield of each a hazelnut ocak was found in per a hectare.

Potassium fertilizer requirement of hazelnut plant was determined according to the Mitcherlich equations modified by Bray (Kacar and Katkat, 2007).

$\log (A-y)=\log A-c_{1} b_{1}$

$\log (A-y)=\log A-c_{l} b_{1}-c x$ follows:

Meanings of the variables in the equations were as

A- The highest yield amount (with $600 \mathrm{~kg} \mathrm{ha}^{-1} \mathrm{~K}_{2} \mathrm{O}$ );

$\mathrm{y}$ - The yield amount (according to applying $\mathrm{K}_{2} \mathrm{O}$ fertilization);

$c_{1}$ - The impact values of potassium in the soil;

$\mathrm{b}_{1}$ - The contents of existing potassium in the soil;

c- The impact values of fertilizer applied to soil;

$\mathrm{x}$ - The amounts of fertilizer to be applied to soil.

Statistical analyses were performed by using analysis of variance in JMP statistical software. Differences at $\mathrm{p}<0.05$ were considered to be significant. Difficulty in calculation was arranged by forming a regression equation between these variables. For obtaining 90\%, 92\%, 94\%, 96\%, 98\% 
265

and $99 \%$ yield for certain levels of potassium (10.0, 25.0, $.750 .0)$, the amounts of fertilizer was calculated. $Y=a+$ $b_{\mathrm{yX}} \mathrm{X}$ equations were constituted from the amounts of fertilizer calculated using the formula. All data obtained were the mean from the three years (Düzgüneş et al., 1983).

\section{Results and discussion}

As seen in Tab. 1, the soils of the experiment orchards have clay loam texture, none salinity, very few $\mathrm{CaCO}_{3}$. The soil reaction changed from 5.67 to 6.29 , organic matter contents from $5.01 \%$ to $6.15 \%$, available phosphorus contents from $84.90 \mathrm{mg} \mathrm{kg}^{-1}$ to $115.31 \mathrm{mg} \mathrm{kg}^{-1}$. The available potassium contents ranged from $67.15 \mathrm{mg} \mathrm{kg}^{-1}$ to 1083.13 $\mathrm{mg} \mathrm{kg}$ depending on applied $\mathrm{K}_{2} \mathrm{SO}_{4}$ fertilizer. The contents of the plant available potassium was determined as "low" in 'Tombul' hazelnut orchards. The extractable soil potassium contents were classified $<50 \mathrm{mg} \mathrm{kg}^{-1}$ "very low", $50-100 \mathrm{mg}$ $\mathrm{kg}^{-1}$ "low", $100-300 \mathrm{mg} \mathrm{kg}$ "adequate", 300-1000 mg kg-1 "much" and >1000 mg kg- "too much" by FAO (1990). In order to determine fertilizer requirements, studied plant nutrients in the soil should be deficient. Gopal (2012) reported that among the three major nutrients, potassium $(\mathrm{K})$ has a special position as evident by its role in increasing the crop yield.

The trial hazelnut ocaks were fertilized with $0 \mathrm{~g}$ ocak $^{-1}$ $800 \mathrm{~g} \mathrm{ocak}^{-1}, 1600 \mathrm{~g} \mathrm{ocak}^{-1}, 2400 \mathrm{~g} \mathrm{ocak}^{-1}$ and $3200 \mathrm{~g} \mathrm{ocak}^{-1}$ $\mathrm{K}_{2} \mathrm{SO}_{4}$ fertilizer in 2009, 2010 and 2011 years. After annual fertilizer application into the hazelnut orchard, the necessary cultural maintenances were made. Each hazelnut ocak was harvested separately in August and the amounts of dry shelled hazelnut yield were determined. The raising potassium fertilization was significantly increased the hazelnut yields (Fig. 1). Genç (1987) stated that potassium was increased 'Tombul' hazelnut yield and decreased the

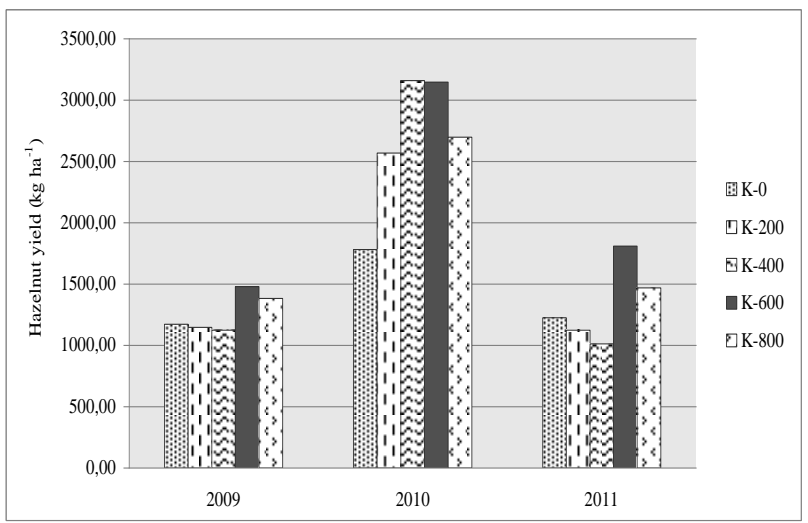

Fig. 1. 'Tombul' hazelnut yields $\left(\mathrm{kg} \mathrm{ha}^{-1}\right)$; LSD(5\%): 154.032

formation of empty nuts. The average $1392.95 \mathrm{~kg} \mathrm{ha}^{-1} \mathrm{dry}$ shelled nuts were obtained from $0 \mathrm{~kg} \mathrm{ha}^{-1}$ application, the average $1850.69 \mathrm{~kg} \mathrm{ha}^{-1}$ yield was obtained from maximum potassium fertilizer dose with $800 \mathrm{~kg} \mathrm{ha}^{-1}$. The highest amount of yield was taken $2145.65 \mathrm{~kg} \mathrm{ha}^{-1}$ with $600 \mathrm{~kg} \mathrm{ha}^{-1}$ $\mathrm{K}_{2} \mathrm{O}$ dose. In this study determined that the maximum product was provided with $600 \mathrm{~kg} \mathrm{da}^{-1} \mathrm{~K}_{2} \mathrm{O}$ fertilizer applications. The more increasing of the amount of potassium fertilizer did not increase yield. The highest yield with the increasing fertilizer doses should be obtained with fertilizer requirement studies. Despite the increasing of the amount of fertilizer, the gradually declining yield should be gained. The yield of a product can be accurately described as minimum laws and declining yield laws (Aktaş, 1994). The laws of declining yield of Mitscherlich reported that the increase in the product obtained by increasing the amount of plant nutrients was not equal to the increase per unit nutrient. This increasing in product gradually

Tab. 1. The effects of potassium fertilizing on some soil properties

\begin{tabular}{ccccc}
\hline $\begin{array}{c}\text { Treatments } \\
\mathrm{K}_{2} \mathrm{O}\left(\mathrm{kg} \mathrm{ha}^{-1}\right)\end{array}$ & Texture & $\begin{array}{c}\mathrm{pH} \\
(1: 3)\end{array}$ & $\begin{array}{c}\mathrm{EC} \\
\left(\mathrm{dS} . \mathrm{m}^{-1}\right)\end{array}$ & $\begin{array}{c}\mathrm{CaCO}_{3} \\
(\%)\end{array}$ \\
\hline 0 & $\mathrm{CL}$ & $6.16 \pm 0.081$ & $0.100 \pm 0.020^{\mathrm{c}}$ & $0.13 \pm 0.021^{\mathrm{d}}$ \\
200 & $\mathrm{CL}$ & $6.29 \pm 0.045$ & $0.090 \pm 0.010^{\mathrm{c}}$ & $0.05 \pm 0.020^{\mathrm{b}}$ \\
400 & $\mathrm{CL}$ & $6.00 \pm 0.323$ & $0.120 \pm 0.017^{\mathrm{c}}$ & $0.09 \pm 0.010^{\mathrm{bc}}$ \\
600 & $\mathrm{CL}$ & $6.07 \pm 0.599$ & $0.140 \pm 0.020^{\mathrm{b}}$ & $0.12 \pm 0.026^{\mathrm{a}}$ \\
800 & $\mathrm{CL}$ & $5.67 \pm 0.272$ & $0.084 \pm 0.021^{\mathrm{a}}$ & $0.11 \pm 0.017^{\mathrm{cd}}$ \\
$\mathrm{LSD}(5 \%)$ & & 0.6008 & 0.03289 & 0.0358 \\
\hline
\end{tabular}

\begin{tabular}{ccccc}
\hline $\begin{array}{c}\text { Treatments } \\
\mathrm{K}_{2} \mathrm{O}\left(\mathrm{kg} \mathrm{ha}^{-1}\right)\end{array}$ & Texture & $\begin{array}{c}\text { Organic Matter } \\
(\%)\end{array}$ & $\begin{array}{c}\text { Available Phosphorus } \\
\left(\mathrm{mg} \mathrm{kg}^{-1}\right)\end{array}$ & $\begin{array}{c}\text { Available Potassium } \\
\left(\mathrm{mg} \mathrm{kg}^{-1}\right)\end{array}$ \\
\hline 0 & $\mathrm{CL}$ & $5.21 \pm 0.943$ & $100.97 \pm 9.332$ & $67.15 \pm 16.087^{\mathrm{b} *}$ \\
200 & $\mathrm{CL}$ & $5.22 \pm 0.861$ & $115.31 \pm 8.405$ & $263.64 \pm 120.468^{\mathrm{b}}$ \\
400 & $\mathrm{CL}$ & $5.34 \pm 0.369$ & $103.24 \pm 12.229$ & $535.50 \pm 329.906^{\mathrm{ab}}$ \\
600 & $\mathrm{CL}$ & $5.01 \pm 0.803$ & $110.69 \pm 14.013$ & $746.33 \pm 441.965^{\mathrm{ab}}$ \\
800 & $\mathrm{CL}$ & $6.15 \pm 0.994$ & $84.90 \pm 25.348$ & $1083.13 \pm 689.808^{\mathrm{a}}$
\end{tabular}

\footnotetext{
* Means ( \pm standard deviation) followed by different letters in the same column are significantly different from each other at $p<0.05$ level. CL: Clay Loam.
} 
decreased according to increasing fertilizer. As seen Fig. 1, potassium fertilizer applications were significantly increased the productivity of hazelnuts. The most suitable potassium fertilization dose in hazelnut agriculture was determined to be $600 \mathrm{~kg} \mathrm{ha}^{1} \mathrm{~K}_{2} \mathrm{O}$ application. For the suitable fertilizer dose recommendations, the economic analysis should be made according to the amount of nuts yield and the amounts of fertilizer.

As a result of this study, $400 \mathrm{~kg} \mathrm{ha}^{-1}$ and $600 \mathrm{~kg} \mathrm{ha}^{-1}(800$ $\mathrm{g} \mathrm{ocak}^{-1}$ and $\left.1200 \mathrm{~g} \mathrm{ocak}^{-1}\right) \mathrm{K}_{2} \mathrm{O}$ doses were recommended in hazelnut agriculture. Di Renzo et al. (2014) reported that food chain control and analysis begin from farm and raw material production to final evaluation of the effects on consumer health. This modelling study could be an useful tool to determine the optimal potassium requirements to guarantee high yields and health benefits and could be well integrated within the Nutrient Hazard Analysis Critical Point process. Genç (1976) reported that the most appropriate fertilization process for hazelnut agriculture was $200 \mathrm{~g} \mathrm{ocak}^{-1} \mathrm{~N}, 300 \mathrm{~g} \mathrm{ocak}^{-1} \mathrm{P}_{2} \mathrm{O}_{5}$ and $750 \mathrm{~g} \mathrm{ocak}^{-1} \mathrm{~K}_{2} \mathrm{O}$ applications. Long term declines in soil $\mathrm{K}$ leading eventually to declining yields was to be avoided, increased use of supplementary fertilizers was required (Sajutha and Bhat, 2012). While the total amounts of nuts were high in 2010 , these amounts were at lower rates in 2009 and 2011. These yield fluctuations occur depending on the vegetable features of hazelnuts (Corylus avellana L.). Yield fluctuations in the 'Tombul' hazelnuts are little or moderate level (Çetiner, 1976). Ayfer et al. (1986) specified that the yield fluctuations are referred to as the "periodicity" and this is seen small amounts in the 'Tombul' hazelnut.

In this study, calculation method related to proportional yield value of Mitscherlich modified by Bray was used, and the data obtained from the studies substituting in the equation was formed Tab. 2. After the 0, 200, 400,600 and $800 \mathrm{~kg} \mathrm{ha}^{-1} \mathrm{~K}_{2} \mathrm{O}$ were applied in hazelnut orchards during three years, the impact values of potassium in the soils and fertilizer were found. The determinations of impact values were used the average amount of obtained the yield and the amount of available potassium contents of the trial hazelnut orchards. Before giving potassium fertilizer to the experiment orchard, the available potassium contents of soils were $49.21 \mathrm{mg} \mathrm{kg}^{-1}, 79.19 \mathrm{mg} \mathrm{kg}^{-1}$ and $83.19 \mathrm{mg} \mathrm{kg}^{-1}$ and these amounts were converted as one hectare. As seen in Tab. 2, the trial orchard soils have $199.60 \mathrm{~kg} \mathrm{ha}^{-1}, 190.10 \mathrm{~kg}$ $\mathrm{ha}^{-1}$ and $118.10 \mathrm{~kg} \mathrm{da}^{-1}$ potassium nutrient elements. The impact values of potassium in the soil were calculated by log $(A-y)=\log A-c_{1} b_{1}$ equation and the mean $c_{1}=0.0026$ was found. The impact values of potassium in the fertilizer were calculated by $\log (A-y)=\log A-c_{1} b_{1}-c x$ equation and the mean $\mathrm{c}=0.0038$ was found.
The impact values of potassium in the soil were calculated as follows:

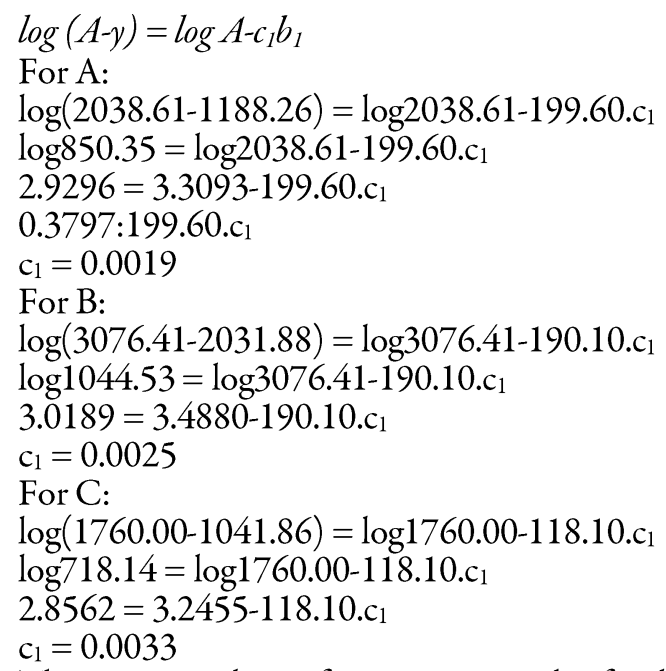

The impact values of potassium in the fertilizer were calculated as follows:

$\log (A-y)=\log A-c_{1} b_{1}-c x$
For A:
$\log (2038.61-2025.09)=\log 2038.61-(0.0026)(199.60)-$ 200.c

$\log 13.52=\log 2038.61-(0.0026)(199.60)-200 . c$

$1.1310=3.3093-0.5190-200 . c$

$1.1310=2.7903-200 . c$

$\mathrm{c}=0.0083$

For B: $200 c$

$\log (3076.41-1543.51)=\log 3076.41-(0.0026)(190.10)-$

$\log 1532.90=\log 3076.41-(0.0026)(190.10)-200 \mathrm{c}$

$3.1855=3.9198-0.3943-200 \mathrm{c}$

$\mathrm{c}=0.0017$

For C: 200c

$\log (1760.00-1273.00)=\log 1760.00-(0.0026)(118.10)-$

$\log 487.00=\log 1760.00-(0.0026)(118.10)-200 c$

$2.6875=3.2455-0.3071-200 c$

$\mathrm{c}=0.0013$

These impact values of potassium $\left(c_{1}\right.$ and $\left.c\right)$ in the soil and in the potassium fertilizer (Tab. 2) was put into the log $(\mathrm{A}-\mathrm{y})=\log \mathrm{A}-\mathrm{c}_{1} \mathrm{~b}_{1}-\mathrm{cx}$ equations.

The amounts of potassium fertilizers were calculated according to the existing potassium content of soils. Then, these calculations were made separately for maximum yields (90\%, 92\%, 94\%, 96\%, 98\% and 99\%). Tab. 3 was consisted of as results of these calculations. Similar calculations were

Tab. 2. The impact values of potassium in the soil and in the potassium fertilizer

\begin{tabular}{|c|c|c|c|c|c|c|c|c|}
\hline & \multicolumn{5}{|c|}{ 'Tombul' hazelnut yields $\left(\mathrm{kg} \mathrm{ha}^{-1}\right)$} & \multirow{2}{*}{$\begin{array}{l}\text { Potassium in the soil } \\
\qquad\left(\mathrm{kg} \mathrm{ha}^{-1}\right) \mathrm{K}_{2} \mathrm{O}\end{array}$} & \multicolumn{2}{|c|}{ Impact Values } \\
\hline & $\begin{array}{c}0 \\
\text { Control } \\
\end{array}$ & $\begin{array}{c}200 \\
\left(\mathrm{~kg} \mathrm{ha}^{-1}\right) \mathrm{K}_{2} \mathrm{O}\end{array}$ & $\begin{array}{c}400 \\
\left(\mathrm{~kg} \mathrm{ha}^{-1}\right) \mathrm{K}_{2} \mathrm{O}\end{array}$ & $\begin{array}{c}600 \\
\left(\mathrm{~kg} \mathrm{ha}^{-1}\right) \mathrm{K}_{2} \mathrm{O}\end{array}$ & $\begin{array}{c}800 \\
\left(\mathrm{~kg} \mathrm{ha}^{-1}\right) \mathrm{K}_{2} \mathrm{O}\end{array}$ & & $\mathrm{c}_{1}$ & $c$ \\
\hline A & 1188.26 & 2025.09 & 1920.68 & 2038.61 & 1512.05 & 199.60 & 0.0019 & 0.0083 \\
\hline B & 2031.88 & 1543.51 & 1743.31 & 3076.41 & 2376.52 & 190.10 & 0.0025 & 0.0017 \\
\hline $\mathrm{C}$ & 1041.86 & 1273.00 & 1631.82 & 1760.00 & 1078.37 & 118.10 & 0.0033 & 0.0013 \\
\hline Mean & & & & & & & 0.0026 & 0.0038 \\
\hline
\end{tabular}


Tab. 3. The amount of potassium nutrient should be used for the each maximum yield level

\begin{tabular}{|c|c|c|c|c|c|c|}
\hline \multirow{2}{*}{$\begin{array}{c}\mathrm{K}_{2} \mathrm{O} \text { contents } \\
\text { of the soil } \\
\left(\mathrm{kg} \mathrm{ha}^{-1}\right)\end{array}$} & \multicolumn{6}{|c|}{$\begin{array}{l}\text { The amounts of potassium to be applied for different maximum yield level } \\
\qquad\left(\mathrm{kg} \mathrm{ha}^{-1} \mathrm{~K}_{2} \mathrm{O}\right)\end{array}$} \\
\hline & $90 \%$ & $92 \%$ & $94 \%$ & $96 \%$ & $98 \%$ & $99 \%$ \\
\hline 10.0 & 256.32 & 281.82 & 314.68 & 361.03 & 440.26 & 519.47 \\
\hline 25.0 & 246.05 & 271.55 & 304.42 & 350.76 & 430.00 & 509.21 \\
\hline 50.0 & 228.95 & 254.45 & 287.32 & 333.66 & 412.89 & 492.11 \\
\hline 75.0 & 211.84 & 237.34 & 270.21 & 316.55 & 395.79 & 475.00 \\
\hline 100.0 & 194.74 & 220.24 & 253.11 & 299.45 & 378.68 & 457.89 \\
\hline 125.0 & 177.63 & 203.13 & 236.00 & 282.34 & 361.58 & 440.79 \\
\hline 150.0 & 160.53 & 186.03 & 218.89 & 265.24 & 344.47 & 423.68 \\
\hline 175.0 & 143.42 & 168.92 & 201.79 & 248.13 & 327.37 & 406.58 \\
\hline 200.0 & 126.32 & 151.82 & 184.68 & 231.03 & 310.26 & 389.47 \\
\hline 225.0 & 109.21 & 134.71 & 167.58 & 213.92 & 293.16 & 372.37 \\
\hline 250.0 & 92.11 & 117.61 & 150.47 & 196.82 & 276.05 & 355.26 \\
\hline 275.0 & 75.00 & 100.50 & 133.37 & 179.71 & 258.95 & 338.16 \\
\hline 300.0 & 57.89 & 83.39 & 116.26 & 162.61 & 241.84 & 321.05 \\
\hline 325.0 & 40.79 & 66.29 & 99.16 & 145.50 & 224.74 & 303.95 \\
\hline 350.0 & 23.68 & 49.18 & 82.05 & 128.39 & 207.63 & 286.84 \\
\hline 375.0 & 6.58 & 32.08 & 64.95 & 111.29 & 190.53 & 269.74 \\
\hline 400.0 & & 14.97 & 47.84 & 94.18 & 173.42 & 252.63 \\
\hline 425.0 & & & 30.74 & 77.08 & 156.32 & 235.53 \\
\hline 450.0 & & & 13.63 & 59.97 & 139.21 & 218.42 \\
\hline 475.0 & & & & 42.87 & 122.11 & 201.32 \\
\hline 500.0 & & & & 25.76 & 105.00 & 184.21 \\
\hline 525.0 & & & & 8.66 & 87.89 & 167.11 \\
\hline 550.0 & & & & & 70.79 & 150.00 \\
\hline 575.0 & & & & & 53.68 & 132.89 \\
\hline 600.0 & & & & & 36.58 & 115.79 \\
\hline 625.0 & & & & & 19.47 & 98.68 \\
\hline 650.0 & & & & & 2.37 & 81.58 \\
\hline 675.0 & & & & & & 64.47 \\
\hline 700.0 & & & & & & 47.37 \\
\hline 725.0 & & & & & & 30.26 \\
\hline 750.0 & & & & & & 13.16 \\
\hline
\end{tabular}

made by Kacar and Katkat (2007) and Güçdemir (2006).

A sample calculation related to Tab. 3 was given below:

$\log (A-y)=\log A-c_{1} b_{1-} c x$

For $\mathrm{y}=90$ and $\mathrm{b}=10.0 \mathrm{~kg} \mathrm{~K}_{2} \mathrm{O}$ :

$\log (100-90)=\log 100-0.0026(10.0)-0.0038 x$

$\log 10=2-0.026-0.0038 \mathrm{x}$

$1=2-0.026-0.0038 \mathrm{x}$

$\mathrm{x}=256.32 \mathrm{~kg} \mathrm{ha}^{-1} \mathrm{~K}_{2} \mathrm{O}$

Difficulty in calculations was arranged by forming a regression equation between these variables.
In order to achieve $90 \%, 92 \%, 94 \%, 96 \%, 98 \%$ and $99 \%$ of maximum yield in certain potassium values (10.0, 25.0, ...750.0), $\mathrm{Y}=\mathrm{a}+\mathrm{b}_{\mathrm{yx}} \mathrm{X}$ equations were constituted from calculated fertilizer amounts. These regression equations were given in Tab. 4 .

Due to $100 \%$ correlation between potassium and the amounts of fertilizer, the hit rating $\left(\mathrm{R}^{2}\right)$ of estimates to be made using the resulting regression models is $100 \%$. The constituted equations were found statistically significant $(\mathrm{p}<0.001)$.

Tab. 4. Regression modelling for recommendation of potassium fertilizer

\begin{tabular}{ccccc}
\hline $\begin{array}{c}\text { Max. Yield } \\
\text { Level }\end{array}$ & $\mathrm{n}$ & $\begin{array}{c}\text { Regression } \\
\text { equation }\end{array}$ & Significance & $\mathrm{R}^{2}$ \\
\hline $90 \%$ & 16 & $90 \%=263.0-0.684 \mathrm{X}$ (Potassium) & ${ }^{*}$ & $100 \%$ \\
$92 \%$ & 17 & $92 \%=289.0-0.684 \mathrm{X}$ (Potassium) & ${ }^{* *}$ & $100 \%$ \\
$94 \%$ & 19 & $94 \%=322.0-0.684 \mathrm{X}$ (Potassium) & ${ }^{* *}$ & $100 \%$ \\
$96 \%$ & 22 & $96 \%=368.0-0.684 \mathrm{X}$ (Potassium) & ${ }^{* *}$ & $100 \%$ \\
$98 \%$ & 27 & $98 \%=447.0-0.684 \mathrm{X}$ (Potassium) & ${ }^{* *}$ & $100 \%$ \\
$99 \%$ & 31 & $99 \%=526.0-0.684 \mathrm{X}$ (Potassium) & $100 \%$ \\
\hline
\end{tabular}

${ }^{* *} . \mathrm{p}<0.001$ 


\section{Conclusions}

In this modelling study, the required amounts of potassium fertilizers were determined in the hazelnut agriculture. Using the Modified Mitcherlich equation, the impact value of present potassium in the soil as $c_{1}=0.0026$, the impact value of potassium in the fertilizer as $c=0.0038$ was determined. Using $\log (\mathrm{A}-\mathrm{y})=\log \mathrm{A}-\mathrm{c}_{1} \cdot \mathrm{b}_{1}-\mathrm{cx}$ equation, the required amounts of potassium fertilizer according to the different potassium nutrient contents in the soil was identified. A new regression equation was formed between these variables in the fertilization table obtained from the study. It was found that $Y=a+b_{y x} X$ equation can be used for the potassium fertilizer recommendations in hazelnut agriculture. For different maximum yield levels, the equations were determined as $Y_{90}=263.0-0.684 \mathrm{X}$, $\mathrm{Y}_{92}=289.0-0.684 \mathrm{X}, \mathrm{Y}_{94}=322.0-0.684 \mathrm{X}, \mathrm{Y}_{96}=368.0-0.684 \mathrm{X}$, $\mathrm{Y}_{98}=447.0-0.684 \mathrm{X}$ and $\mathrm{Y}_{99}=526.0-0.684 \mathrm{X}$. Due to $100 \%$ correlation between present potassium in the soil and amounts of fertilizer to be applied, hit ratings $\left(R^{2}\right)$ of the fertilizer recommendations which will be made with these regression models are $100 \%$. With the use of the results of this modelling study, potassium fertilizer recommendations can be done easily for hazelnut agriculture and similar equations can be created for other plants. In addition, fertilizer recommendations could be possible with a single equation when performed economic analysis. In conclusion, this modelling study could be an useful tool to determine the optimal potassium requirements to guarantee high yields and health benefits and could be well integrated within the Nutrient Hazard Analysis Critical Point process.

\section{References}

Aktaş M (1994). Plant nutrition and soil fertility. Ankara University, Publications of Agriculture Faculty:1361, Ankara (in Turkish), $344 \mathrm{p}$.

Anonymous (2012). Annual report. Directorate of Food, Agriculture and Livestock in Giresun and Trabzon (in Turkish).

Ayfer M, Uzun A, Baş F (1986). Turkish hazelnut varieties. Black Sea Hazelnut Exporters Association, Giresun (in Turkish), 95p.

Brady NC, Weil RR (2007). The nature and properties of soils. 14th ed. Englewood Cliffs (NJ): Prentice-Hall.

Bray RH, Kurtz LT (1945). Determination of total organic and available forms of phosphorus in soils. Soil Science 45:39-45.

Çağlar KÖ (1958). Soil science. Ankara University, Publications of Agriculture Faculty, Ankara (in Turkish).

Çetiner E (1976). Type selection studies them with the selection of research on pollinators in Tombul varieties around the Black Sea region and especially Giresun and around. Ph.D thesis, Ankara University, Ankara (in Turkish), $174 \mathrm{p}$.

Di Renzo L, Carraro A, Minella D, Botta R, Contessa C, Sartor C, Iacopino AM, De Lorenzo A (2014). Nutrient analysis critical control point (NACCP): Hazelnut as a prototype of nutrigenomic study. Food and Nutrition Sciences 5:79-88.

Duyar Ö, Özenç N (2013). Plant nutrition in hazelnuts and fertilization techniques. Food, Agriculture and Livestock Ministry, General Directorate of Agricultural Research and Policy, Hazelnut Research Station, Giresun (in Turkish), 96p.

Düzgüneş O, Kesici T, Gürbüz F (1983). Statistical methods-I. Ankara University, Publications of Agriculture Faculty No:862, Ankara (in Turkish).

FAO (1990). Micronutrient assessment at the country level: An international study. FAO Soil Bulletin by Sillanpaa, Rome.

FAO (2012). Agricultural statistics. Food and Agricultural Organization of the United Nations, http:॥www.faostat.fao.org

Genç Ç (1976). A Research on the effects of fertilization on yield and quality in Giresun hazelnut varieties in Tombul. Ph.D thesis, Ankara University, Faculty of Agriculture, Ankara (in Turkish), $86 \mathrm{p}$.

Genç Ç (1987). Effects of potassium on hazelnut yield and some nut quality characteristics in Tombul varieties in Giresun. IPI. International Fertilizer Industry Seminar, 6-7 October, Ankara (in Turkish).

Gopal R (2012). Impact of variable potassium on metabolism, oil and seed quality of groundnut. Communications in Soil Science and Plant Analysis 43:2504-2511.

Güçdemir İH (2006). Turkey fertilizers and fertilization guide. Ministry of Agriculture and Rural Affairs, General Directorate of Agricultural Research, Soil and Fertilizer Research Institute Publication No:231, Technical Publication No:T69, Ankara (in Turkish), 424 p.

Kacar B, Katkat AV (2007). Fertilizers and fertilization technique. Nobel Publications No:1119, Science and Biology Publication Series:34, 2. Ed, (in Turkish), $560 \mathrm{p}$.

Knudsen D, Peterson GA, Pratt PF (1982). Lithium, sodium and potassium. Methods of soil analysis, Part II, ASA-SSSA, WI, 225-245.

Köksal Aİ (2002). Turkish hazelnut varieties. Hazelnut Promotion Group, The Black Sea Hazelnut and Products Exporters' Association, Giresun (in Turkish), 136p.

Krebs RE (2006). The history and use of our earth's chemical elements: a reference guide ( $2^{\text {nd }}$ ed.). Greenwood Publishing Group.

Marschner H (1995). Mineral nutrition of higher plants ( $2^{\text {nd }} \mathrm{ed}$.). London: Academic Press.

Mengel K (2007). Potassium. In: Barker AV. Pilbeam DJ. Editors, Handbook of plant nutrition. Boca Raton (FL): CRC Press 91-121.

Nelson DW, Sommers LE (1982). Total carbon, organic carbon and soil organic matter. In: Methods of soil analysis, Part II. ASA-SSSA, Madison, WI, 539-579.

Okay AN, Kaya A, Küçük VY, Küu̧ük A (1986). Hazelnut agriculture. T.C. T.O.K.B. General Directorate of Organization and Support. Publication No: General 142, TEDGEM-12 (in Turkish).

Özenç N, Kara İ, Bender Özenç D (2005). General soil properties and conditions for using fertilizers and soil products in the 
Tombul hazelnut orchards of Giresun. Acta Hort 686:319326.

Özyazıcı MA, Aydoğan M, Bayraklı B, Kesim E, Şeker F, Dengiz O, Urla Ö, Yıldız H, Ünal E (2013). Determination of Middle and Eastern Black Sea region agricultural land, plant nutrients and potentially toxic elements, the creation of the database and mapping. Black Sea Agricultural Research Institute, Final Report, Samsun (in Turkish), 297 p.

Sujatha S, Bhat R (2012). Impacts of vermicompost and nitrogen, phosphorus, and potassium application on soil fertility status in arecanut grown on a laterite soil. Communications in Soil Science and Plant Analysis 43:2400-2412.

Soil Survey Staff (1951). Soil survey manual. USDA Handbook 18, Washington D.C., USA.
Turkish Hazelnut Exporter's Union (2012). The Turkish hazelnut. Turkish Hazelnut Exporter's Union, Giresun (in Turkish).

US Salinity Lab Staff (1954). Diagnosis and Improvement of saline and alkali soils. USDA. Agricultural Handbook, No:60, $160 \mathrm{p}$.

Ünal A (2007). Modern hazelnut agriculture. Burak Publications, Ankara (in Turkish), $231 \mathrm{p}$.

Very AA, Sentenac H (2003). Molecular mechanisms and regulation of $\mathrm{K}^{+}$transport in higher plants. Annual Reviews in Plant Biology 54:573-603. 